\title{
USTAWA Z DNIA 11 LIPCA 2014 R. O PETYCJACH - UWAGI KRYTYCZNE
}

\section{WPROWADZENIE}

Konstytucja Rzeczypospolitej Polskiej z 2 kwietnia 1997 r. ${ }^{1}$ stanowi w art. 63: „Każdy ma prawo składać petycje, wnioski i skargi w interesie publicznym, własnym lub innej osoby za jej zgodą do organów władzy publicznej oraz do organizacji i instytucji społecznych w związu z wykonywanymi przez nie zadaniami zleconymi z zakresu administracji publicznej. Tryb rozpatrywania petycji, wniosków i skarg określa ustawa”. Dyrektywy proceduralne wskazujące sposób urzeczywistniania materialnej treści prawa petycji zawiera szereg ustaw zwykłych oraz rozporządzeń wykonawczych. Podstawowe znaczenie przypisuje się ustawie z 14 czerwca 1960 r. - Kodeks postępowania administracyjnego ${ }^{2}$, która w dziale VIII normuje postępowanie uproszczone w sprawie przyjmowania i rozpatrywania skarg i wniosków. Pojęcie petycji zostało wprowadzone do art. 221 nowelizacją Kodeksu postępowania administracyjnego z 29 grudnia 1998 r. ${ }^{3}$, jednakże w przeciwieństwie do skargi (art. 227 k.p.a.) i wniosku (art. 241 k.p.a.), jej przedmiot nie został zdefiniowany. Był to jedyny przepis odnoszący się wprost do petycji. W następnych artykułach ustawodawca konsekwentnie używał już tylko dwóch terminów: wniosek i skarga. Regulacja ta wywoływała daleko idące rozbieżności związane ze stosowaniem działu VIII k.p.a. do rozpatrywania petycji. W orzecznictwie sądowoadministracyjnym i nauce prawa administracyjnego przeważał pogląd, iż do rozpatrywania petycji - zależnie od jej treści - należy stosować odpowiednio przepisy dotyczące skarg lub wniosków ${ }^{4}$. Pojawiały się również uwagi krytycz-

\footnotetext{
${ }^{1}$ Dz. U. Nr 78, poz. 483 ze zm.

${ }^{2}$ Ustawa z 14 czerwca 1960 r. - Kodeks postępowania administracyjnego, t.jedn.: Dz. U. 2016, poz. 23 ze zm. (dalej jako: k.p.a.).

${ }^{3}$ Ustawa z 29 grudnia 1998 r. o zmianie niektórych ustaw w związku z wdrożeniem reformy ustrojowej państwa, Dz. U. Nr 162, poz. 1126

${ }^{4}$ Zob. wyrok WSA w Łodzi z 8 listopada 2007 r., III SA/Łd 487/07; J. Borkowski, w: B. Adamiak, J. Borkowski, Kodeks postepowania administracyjnego. Komentarz, Warszawa 2009, s. 668; W. Sokolewicz, Uwagi do art. 63, w: L. Garlicki (red.), Konstytucja Rzeczypospolitej Polskiej. Komentarz, t. 5, Warszawa 2007, s. 4; A. Jaroszyński, Opinia w sprawie projektu ustawy o petycjach, w: Opinie prawne na temat projektu ustawy o petycjach, Opinie i Ekspertyzy OE-115, Kancelaria Senatu, Warszawa 2009, s. 10; M. Wierzbowski (red.), Postepowanie administracyjne, Warszawa 2005, s. 244; J. Lang, Wybrane problemy prawnej regulacji wykonywania prawa do
} 
ne, iż przepisy k.p.a. nie wypełniają w pełni nakazu sformułowanego w art. 63 zd. 2 Konstytucji ${ }^{5}$. Stąd też liczne postulaty dostosowania ustawodawstwa zwykłego do przepisów Konstytucji, tj. wyraźnego unormowania trybu rozpatrywania petycji. Prace legislacyjne w tym zakresie były podejmowane od 1999 r. Ich zwieńczeniem jest ustawa o petycjach przyjęta 11 lipca $2014 \mathrm{r}^{6}{ }^{6}$ Celem niniejszego artykułu jest analiza normatywna tego aktu, zwłaszcza zaś wskazanie najistotniejszych mankamentów dotyczących kształtu i treści ustawy o petycjach.

\section{PRZEBIEG PRAC LEGISLACYJNYCH NAD USTAWOWYM UREGULOWANIEM PETYCJI}

Prace nad ustawowym uregulowaniem podstawowych kwestii związanych z wykonywaniem petycji podejmowane były kilkukrotnie. W październiku 1999 r. rząd złożył do Sejmu projekt ustawy o zmianie kodeksu postępowania administracyjnego ${ }^{7}$. Spotkał się on jednak z nieprzychylnym przyjęciem ze strony ekspertów Biura Studiów i Ekspertyz Kancelarii Sejmu. Główny zarzut odnosił się do nieprecyzyjnego i nieodpowiadającego postanowieniom art. 63 Konstytucji określenia przedmiotu petycji. Zdaniem ekspertów sformułowanie, iż „przedmiotem petycji mogą być w szczególności sprawy określone dla skarg i wniosków, jeśli dotyczą zagadnień życia zbiorowego" zawiera w sobie niedostatecznie ostre wyrażenie „zagadnienia życia zbiorowego”, które nie jest ani zdefiniowane w k.p.a., ani też łatwe do oddzielenia od interesu publicznego ${ }^{8}$. W konsekwencji Komisja Nadzwyczajna do spraw zmian w kodyfikacjach o rządowym projekcie ustawy o zmianie ustawy - Kodeks postępowania administracyjnego rekomendowała Sejmowi RP odrzucenie projektu ustawy9. 6 września 2000 r. przyjęto sprawozdanie o odrzuceniu projektu, który z dniem 23 listopada 2000 r. został przez Radę Ministrów wycofany z Sejmu.

Następną próbę ustawowego unormowania trybu rozpatrywania petycji podjęto dopiero w $2009 \mathrm{r}$. Z inicjatywy rządu został opracowany projekt ustawy o zmianie k.p.a. ${ }^{10}$ Projektodawcy zakładali dodanie nowego rozdziału 3a „Petycje”, jednakże po uzgodnieniach resortowych i jego krytycznej ocenie zre-

sktadania skarg $i$ wniosków, „Acta Universitatis Wratislaviensis”. Prawo CLXVIII, Wrocław 1990, s. 167.

${ }^{5}$ B. Banaszak, Opinia na temat projektu ustawy o petycjach, w: Opinie prawne..., s. 4; K. Działocha, Prawo petycji w obowiazujacym ustawodawstwie i proponowane kierunki zmian, w: Prawo petycji $w$ ustawodawstwie polskim, Opinie i Ekspertyzy OE-85, Warszawa 2008; H. Zięba-Załucka, Prawo petycji w Rzeczypospolitej Polskiej, „Przegląd Prawa Konstytucyjnego” 2010, nr 4, s. 9-21.

${ }^{6}$ Dz. U. 2014, poz. 1195.

${ }^{7}$ Rządowy projekt ustawy o zmianie ustawy - Kodeks postępowania administracyjnego, Sejm III kadencji, Druk nr 1453.

${ }^{8}$ Pismo MSWiA do RPO J. Kochanowskiego, nr BMP-079-3565/08/AK.

${ }^{9}$ Sprawozdanie Komisji Nadzwyczajnej do spraw zmian w kodyfikacjach o rządowym projekcie ustawy o zmianie ustawy - Kodeks postępowania administracyjnego (druk nr 1453), Sejm III kadencji, Druk nr 2/78.

${ }^{10}$ Projekt ustawy o zmianie ustawy - Kodeks postępowania administracyjnego, www.bip. msw.gov.pl/download.php?s=4\&id=4710 [dostęp: 11.09.2014]. 
zygnowano z nowelizacji. Główny zarzut sprowadzał się do nieprecyzyjnego określenia przedmiotu petycji. Podobnie bowiem jak w projekcie nowelizacji k.p.a. z 1999 r., przedmiotem petycji miały być sprawy określone dla skarg i wniosków, jeśli dotyczyły zagadnień życia zbiorowego.

Kolejny, tym razem senacki projekt ustawy o petycjach ${ }^{11}$ wniesiono do Sejmu 14 kwietnia 2011 r. ${ }^{12}$, jednakże koniec kadencji parlamentu spowodował, że prace nad nim - zgodnie z zasadą dyskontynuacji - zostały zamknięte. Senat VIII kadencji podjął na nowo prace legislacyjne w tym zakresie. 18 grudnia 2013 r. został przekazany do Sejmu projekt ustawy o petycjach (druk senacki nr 285) stanowiący powtórzenie poprzedniego, senackiego projektu. Prace legislacyjne zakończyły się uchwaleniem 11 lipca 2014 r. ustawy o petycjach, która weszła w życie 6 września 2015 r. Tak długi okres vacatio legis podyktowany był koniecznościa przygotowania się podmiotów właściwych do rozpatrywania petycji, zwłaszcza w zakresie utworzenia bądź modernizacji stron internetowych, na których będą zamieszczane informacje dotyczące petycji.

Ustawa z 11 lipca 2014 r. o petycjach reguluje zasady składania i rozpatrywania petycji, sposób postępowania oraz właściwość organów w sprawach dotyczących petycji. Założeniem projektodawcy było „osiągnięcie jednoznacznej i pełnej zgodności z postanowieniami Konstytucji RP poprzez skonkretyzowanie i dookreślenie prawa petycji w odrębnej ustawie”, czego skutkiem miało być uporządkowanie dotychczasowego stanu prawnego w tym zakresie ${ }^{13}$. Tymczasem już nawet pobieżna lektura nowej ustawy pozwala dostrzec liczne mankamenty i problemy związane ze stosowaniem jej przepisów.

\section{PRZEDMIOT PETYCJI}

Z całkowitą dezaprobatą należy odnieść się do enigmatycznie zakreślonego przedmiotu petycji. W myśl art. 2 ust. 3 przedmiotem petycji może być żądanie, w szczególności zmiany przepisów prawa, podjęcia rozstrzygnięcia lub innego działania w sprawie dotyczącej podmiotu wnoszącego petycję, życia zbiorowego lub wartości wymagajacych szczególnej ochrony w imię dobra wspólnego, mieszczących się w zakresie zadań i kompetencji adresata petycji. W założeniu projektodawcy ustawa miała „konkretyzować i dookreślić prawo petycji”, a tymczasem ani nie definiuje w sposób wyraźny i jednoznaczny pojęcia petycji ${ }^{14}$, ani nie odróżnia petycji od skarg i wniosków ${ }^{15}$.

11 Senat RP, VII kadencja, Druk nr 1036.

${ }_{12}$ Uchwała Senatu RP z 14 kwietnia 2011 r. w sprawie wniesienia do Sejmu projektu ustawy o petycjach, 74. posiedzenie Senatu RP, VII kadencja.

${ }^{13}$ Uzasadnienie do projektu ustawy o petycjach, Senat RP, VIII kadencja, Druk nr 285.

${ }^{14} \mathrm{~W}$ trakcie prac legislacyjnych Prokurator Generalny wyraził pogląd, iż „zasadniczą wadą proponowanej definicji pojęcia petycji jest jej niewielka funkcjonalność, wynikająca z przyjęcia nazbyt otwartego sposobu ukształtowania jej treści, w rezultacie którego w pojęciu tym będzie mieścić się praktycznie każde żądanie jakiegokolwiek działania”. Stanowisko Prokuratora Generalnego do druku nr 2135, PG VII G 025-18/14, Warszawa, 19 lutego 2014 r., s. 4.

15 Zob. S. Gajewski, Petycja, skarga, wniosek. Uwagi na marginesie Ustawy z dnia 11 lipca 2014 r. o petycjach, „Przegląd Prawa Publicznego” 2014, nr 4, s. 157-168; S. Gajewski, A. Jakubowski, 
Warto przypomnieć, że ustalenie wzajemnych relacji między tymi trzema środkami oraz wyznaczenie linii demarkacyjnej - zwłaszcza między petycjami a skargami i wnioskami - od samego początku obowiąywania Konstytucji było problematyczne i skutkowało licznymi sporami doktrynalnymi. Zasadniczo stanowiska przedstawicieli nauki prawa można ująć w trzy kategorie. Według pierwszego z nich petycja jest instytucją różną od skarg i wniosków, odrębności zaś między nimi związane są z przedmiotem tych środków (H. Zięba-Załucka ${ }^{16}$, K. Działocha ${ }^{17}$ ), bądź kręgiem adresatów zobowiązanych do ich przyjmowania (B. Banaszak ${ }^{18}$ ). Przedstawiciele drugiego stanowiska twierdzą że petycję - w zależności od przedmiotu - należy traktować analogicznie do skargi lub wniosku (M. Wierzbowski ${ }^{19}$, A. Jaroszyńskii ${ }^{20}$ J. Borkowski ${ }^{21}$ ). Z kolei reprezentanci trzeciego stanowiska uważaja, że art. 63 Konstytucji statuuje prawo petycji, na które składają się trzy instytucje: petycje sensu stricto (o charakterze zbiorowym) oraz indywidualne wnioski i skargi (J. P. Tarno ${ }^{22}$, L. Wiśniewski ${ }^{23}$, W. Sokolewicz ${ }^{24}$, J. Lipski ${ }^{25}$, W. Orłowski ${ }^{26}$ ). Uchwalona 11 lipca 2014 r. ustawa o petycjach wątpliwości co do wzajemnych zależności między tymi trzema środkami nie rozstrzygnęła.

Postępowanie prowadzone na skutek złożenia petycji jest odformalizowanym środkiem obrony i ochrony różnych interesów jednostki, które nie dają podstaw do żądania wszczęcia postępowania administracyjnego ani téz nie stanowia podstawy powództwa lub wniosku zmierzającego do wszczęcia postępowania sądowego. Nie może być ono konkurencyjne w stosunku do żadnej innej prawnie uregulowanej procedury stosowanej przed organami władzy publicznej ${ }^{27}$. Petycję zaliczyć można do tzw. miękkich instrumentów, gdyż złożenie jej nie prowadzi bezpośrednio do rozstrzygnięć ze skutkiem prawnym i nie ma bezpośredniego wpływu na żadną decyzję organu władzy publicznej. Petycje nie służą również zwalczaniu stanu bezczynności zaistniałego w konkretnej, indywidu-

Petycje, skargi i wnioski. Dziat VIII Kodeksu postepowania administracyjnego. Ustawa o petycjach. Komentarz, Warszawa 2015; J. Jaśkiewicz, Komentarz do ustawy o petycjach, System Informacji Prawniczej Lex (Wolters Kluwer), Warszawa 2015.

${ }^{16}$ H. Zięba-Załucka, op. cit., s. 18.

${ }^{17}$ K. Działocha, op. cit., s. 2 i 4.

${ }_{18}$ Autor ten twierdzi, że petycje mają tradycyjnie szerszy krąg adresatów niż skargi i wnioski, obejmujący również Sejm i Senat. B. Banaszak, Opinia na temat projektu ustawy o petycjach, w: Opinie prawne, s. 5.

${ }_{19}$ M. Wierzbowski, w: idem (red.), op. cit., s. 244.

${ }^{20}$ A. Jaroszyński, Opinia w sprawie projektu ustawy o petycjach, w: Opinie prawne, s. 10.

${ }^{21}$ J. Borkowski, op. cit., s. 668.

${ }^{22}$ J.P. Tarno, w: W. Chróścielewski, J. P. Tarno, Postępowanie administracyjne i postępowanie przed sqdami administracyjnymi, Warszawa 2011, s. 271.

${ }^{23}$ Wypowiedź L. Wiśniewskiego, w: Biuletyn z XVI Posiedzenia KKZN w 21-22 III 1995, Warszawa 1995, s. 66.

${ }^{24}$ Por. W. Sokolewicz, Uwagi do art. 63, w: L. Garlicki (red.), op. cit., s. 4.

${ }_{25}$ J. Lipski, Prawo do petycji, skarg $i$ wniosków w polskim systemie prawnym, „Zeszyty Prawnicze BSE” 2004, nr 4(4), s. 119.

${ }^{26}$ W. Orłowski, Prawo sktadania petycji, wniosków i skarg, w: M. Chmaj et al., Wolności $i$ prawa polityczne, Kraków 2002, s. 159; idem, Konstytucyjne uwarunkowania prawa petycji, w: Prawo petycji..., s. 11.

27 J. Borkowski, op. cit., s. 837, 860; wyrok NSA z 1 grudnia 1998 r., III SA 1636/97. 
alnej sprawie. W tym bowiem przypadku jednostka ma do dyspozycji znacznie skuteczniejsze środki prawne, mianowicie skargę do sądu administracyjnego na bezczynność lub przewlekłe prowadzenie postępowania przez organ administracji publicznej, bądź też skargę na naruszenie prawa strony do rozpoznania sprawy w postępowaniu przygotowawczym prowadzonym lub nadzorowanym przez prokuratora i postępowaniu sądowym bez nieuzasadnionej zwłoki. Wydaje się, że w założeniu ustawodawcy petycja miała być narzędziem ograniczającym bierność organów władzy publicznej i stanowiącym impuls do podjęcia określonego działania. Można jednak zauważyć, że taką funkcję spełnia już wniosek, a także skarga, której przedmiotem może być m.in. zaniedbanie, nienależyte wykonywanie zadań, naruszenie praworządności, a także przewlekłe lub biurokratyczne załatwianie spraw (art. 227 k.p.a.) ${ }^{28}$.

Przyjęte przez ustawodawcę rozwiązania zasługują na krytyczną ocenę. Przede wszystkim poważne problemy interpretacyjne wywołują sformułowania „życie zbiorowe” oraz „wartości wymagające szczególnej ochrony w imię dobra wspólnego". Konieczne będzie nie tylko wypełnienie ich własna, konkretna treścia, ale przede wszystkim oddzielenie od interesu publicznego, w którym to również mogą być składane skargi i wnioski. Stosownie do art. 241 k.p.a. przedmiotem wniosku mogą być w szczególności: sprawy ulepszenia organizacji, wzmocnienia praworządności, usprawnienia pracy i zapobiegania nadużyciom, ochrony własności, lepszego zaspokajania potrzeb ludności. Z tego przykładowego wyliczenia wynika, że równie dobrze przedmiotem wniosku mogą być sprawy objęte art. 2 ust. 3 ustawy o petycjach, bądź też przedmiotem petycji mogą być sprawy właściwe dla wniosków (art. 241 k.p.a.). Z cała bowiem pewnościa „wartością wymagającą szczególnej ochrony w imię dobra wspólnego" jest praworządność - zarówno jej wzmocnienie (art. 241 k.p.a.), jak i przeciwdziałanie jej naruszeniom (art. 227 k.p.a.).

Niezależnie od wskazanych powyżej zastrzeżeń należy zwrócić uwagę, że sformułowanie „wartości wymagające szczególnej ochrony w imię dobra wspólnego" jest rodzajem odesłania pozaprawnego. W wykładni tego pojęcia wyraźnie zauważalny jest udział argumentacji aksjologicznej, kreujaccej luz decyzyjny organu właściwego do rozpatrzenia petycji. Organ będzie ustalał jego znaczenie normatywne a casu ad casum, gdyż kategoria „wartości wymagające szczególnej ochrony w imię dobra wspólnego" nie poddaje się łatwo obiektywizacji. Każdorazowo organ będzie zobowiązany ustalić, czy żądanie przedstawione przez jednostkę dotyczy „wartości”, a jeśli tak, to czy wymaga ona „ochrony w imię dobra wspólnego”. Zauważyć przy tym należy, że wartość ta musi wymagać nie jakiejkolwiek, ale „szczególnej” ochrony, co pozostawia organowi szerokie możliwości wartościowania.

Krytycznie należy także ustosunkować się do wyeksponowania przez ustawodawcę kryterium „życia zbiorowego”, które było już proponowane w przywołanych projektach nowelizacji k.p.a. z 1999 i 2009 r. Wówczas propozycja ta została przez Komisję Nadzwyczajną do spraw zmian w kodyfikacjach oraz ekspertów zaopiniowana negatywnie. W ustawie z 11 lipca

\footnotetext{
${ }^{28}$ E. Wójcicka, Prawo petycji w Rzeczypospolitej Polskiej, Warszawa 2015, s. 26.
} 
2014 r. o petycjach z niezrozumiałych powodów powrócono do rozwiązania, które dwukrotnie zostało ocenione krytycznie. W praktyce wyznaczenie linii demarkacyjnej między „życiem zbiorowym” a „potrzebami ludności”, które moga być przedmiotem wniosków, będzie wiązało się z istotnymi trudnościami. Niewiele w tym względzie ułatwia przyjęta przez ustawodawcę zasada, że o tym, czy pismo jest petycja, decyduje jego treść, a nie forma zewnętrzna (art. 3 u.o.p.). Ogólnikowość sformułowań nie pozwala w sposób pewny i bezdyskusyjny odróżnić petycji od skarg i wniosków, a więc to od uznania organu będzie zależało, czy żądanie jednostki (np. związane z usprawnieniem komunikacji miejskiej) będzie kwalifikowane jako wniosek (,lepsze zaspakajanie potrzeb ludności”), czy też jako petycja (,sprawy dotyczące życia zbiorowego"). Zawarte w analizowanym przepisie wyrażenia „wartości wymagajace szczególnej ochrony w imię dobra wspólnego”, „podjęcia rozstrzygnięcia lub innego działania w sprawie [...] życia zbiorowego" sa nieostre, nieprecyzyjne i wieloznaczne, co nie tylko uniemożliwia uprawnionemu do złożenia petycji zrozumienie przepisu oraz ocenę szans na jej pozytywne załatwienie, ale również łączy się z trudnościami interpretacyjnymi organów, a tym samym ryzykiem rozbieżności i błędnej praktyki stosowania prawa.

\section{PODMIOTY UPRAWNIONE DO ZLOŻENIA PETYCJI}

Zakres podmiotowy prawa petycji został uregulowany w art. 2 ust. 1 ustawy, zgodnie z którym petycja może być złożona przez osobę fizyczna, osobę prawną jednostkę organizacyjną niebędącą osobą prawną. Można mieć zastrzeżenia, czy doprecyzowanie podmiotów uprawnionych do złożenia petycji było konieczne, zwłaszcza że w art. $221 \S 1$ k.p.a., który również realizuje art. 63 Konstytucji, ustawodawca użył pojęcia „każdy”29. Już na etapie prac legislacyjnych zwracano uwagę, że zakres podmiotowy prawa petycji nie powinien odbiegać od sposobu jego konstytucyjnego ujęcia. Jak słusznie zauważyła Monika Florczak-Wątor, jeśli „intencją autorów nie była modyfikacja kręgu podmiotów uprawnionych do wniesienia petycji, to najlepszym rozwiązaniem byłoby pozostawienie szerokiej formuły wyrażonej $\mathrm{w}$ treści art. 63 Konstytucji za pomoca pojęcia „każdy” ${ }^{30}$. Tym bardziej że stworzenie zamkniętego katalogu podmiotów uprawnionych z prawa petycji nie jest ani możliwe, ani celowe.

Zwrócić należy uwagę na niezbyt precyzyjne pojęcie „osoby prawnej”, które może sugerować, że uprawnione są nie tylko osoby prawne prawa prywatnego, ale również wszelkie osoby prawne prawa publicznego.

${ }^{29}$ Tak też: K. Kubuj, Opinia prawna na temat senackiego projektu ustawy o petycjach (druk nr 4261), Warszawa, 27 czerwca 2011 r., s. 6.

${ }^{30}$ M. Florczak-Wator, Opinia prawna na temat senackiego projektu ustawy o petycjach, „Zeszyty Prawnicze Biura Analiz Sejmowych” 2014, nr 2, s. 189. 
Zakres podmiotowy prawa petycji wyznacza, po pierwsze, charakter tego prawa (publiczne prawo podmiotowe o charakterze politycznym), po drugie, status prawny danego podmiotu - rozumiany jako zdolność bycia podmiotem publicznych praw podmiotowych. Istota prawa petycji nie sprzeciwia się korzystaniu z niego przez inne niż osoby fizyczne podmioty. Niewątpliwie jednak istnieje wyraźna różnica między pozycją prawną osoby fizycznej i osoby prawa prywatnego a statusem np. jednostki samorządu terytorialnego jako publicznej osoby prawnej, sprawującej władzę publiczną w zakresie powierzonych jej zadań. Doktryna i orzecznictwo sa zgodne co do tego, że odmienny status osób prawa prywatnego i publicznego istotnie wpływa na zakres przysługujących im praw i wolności. Osoba fizyczna wykonuje swoje prawa i wolności swobodnie, aczkolwiek w granicach prawnie dozwolonych. Natomiast podmiot prawa publicznego korzysta ze swych praw w celu realizacji zadań publicznych ${ }^{31}$. Skoro prawo petycji jest prawem jednostki, to nie może przysługiwać takim osobom prawnym prawa publicznego jak np. Skarb Państwa czy jednostki samorządu terytorialnego. Przyjąć również należy, że podmiotem uprawnionym z prawa petycji nie może być żaden organ władzy publicznej ${ }^{32}$. Konstrukcja prawa podmiotowego, którego beneficjentem miałby być podmiot władzy publicznej, prowadziłaby do utożsamienia podmiotów zobowiązanych do zapewnienia realizacji danego prawa $\mathrm{z}$ ich nosicielami ${ }^{33}$.

Nieco inaczej przedstawia się sytuacja tzw. publicznych podmiotów gospodarczych. Coraz szerszą akceptację uzyskuje pogląd, iż podmioty te powinny być uprawnione do korzystania z niektórych konstytucyjnych praw i wolności, wówczas, gdy znajdują się w takiej samej sytuacji jak osoby fizyczne i inne osoby prawne ${ }^{34}$. Stanowisko to uzasadniane jest „dążeniem do wzmocnienia ochrony podmiotów prawa publicznego oraz potrzebą intensyfikacji ochrony jednostek wchodzacych w ich skład. Podmiotom prawa publicznego, takim jak uniwersytety, przedsiębiorstwa państwowe, izby lekarskie itp., można przyznać prawa konstytucyjnie gwarantowane jednostkom wówczas, gdy nie działają one jako podmioty wyposażone w atrybuty władzy państwowej, a ich pozycja jest w stosunkach prawnych porównywalna z pozycją osób fizycznych lub osób prawnych prawa cywilnego" ${ }^{35}$. Ewolucja poglądów w zakresie zdolności publicznych podmiotów gospodarczych do bycia beneficjentem konstytucyjnych praw i wolności stawia nowe wyzwania również przed organami stosującymi ustawę o petycjach.

${ }^{31}$ Postanowienie TK z 22 maja 2007 r., SK 70/05, OTK Z.U. 2007, nr 6A, poz. 60; L. Garlicki, Polskie prawo konstytucyjne, Warszawa 2010, s. 99; M. Masternak-Kubiak, P. Kuczma, Prawo petycji jako publiczne prawo podmiotowe (aspekt podmiotowy i przedmiotowy), w: R. Balicki, M. Jabłoński (red.), Teoretyczne i praktyczne aspekty realizacji prawa petycji, Wrocław 2015, s. 271.

${ }^{32}$ M. Florczak-Wątor, Komentarz do art. 63, w: M. Safjan, L. Bosek (red.), Komentarz do Konstytucji RP, t. 1, Legalis 2016.

${ }^{33}$ Por. postanowienie TK z 6 lutego 2001 r., TS 148/00, OTK Z.U. 2001, nr 3, poz. 72.

${ }_{34}$ Postanowienie TK z 18 grudnia 2013 r., Ts 13/12, OTK Z.U. 2014, nr II/B, poz. 833.

${ }^{35}$ Federalny Trybunał Konstytucyjny przychylił się do tej opinii. Zob. B. Banaszak, System konstytucyjny Niemiec, Warszawa 2005, s. 38. 


\section{ASPEKTY PROCEDURALNE SKLADANIA I ROZPATRYWANIA PETYCJI}

Zwrócić należy uwagę na pewne aspekty proceduralne wykonywania petycji, wywołujące poważne zastrzeżenia co do swej celowości, a nawet racjonalności. Z niejasnych powodów ustawodawca znacznie ograniczył dopuszczalna formę składanych petycji. Petycje można składać jedynie w formie pisemnej albo za pomocą środków komunikacji elektronicznej. Jakkolwiek rezygnacja z wnoszenia petycji telegraficznie, za pomoca dalekopisu lub telefaksu z uwagi na anachronizm tych urządzeń - nie wywołuje większego sprzeciwu, to brak wnoszenia petycji ustnie do protokołu budzi zastrzeżenia. Rozwiązanie to niepotrzebnie ogranicza możliwość wnoszenia petycji przez osoby, które nie moga lub nie potrafią pisać ${ }^{36}$.

Zastrzeżenia wywołuja zasady składania petycji zbiorowych. Przede wszystkim zastanawiajacca i niezrozumiała jest rezygnacja $\mathrm{z}$ wymogu potwierdzenia poparcia dla inicjatywy własnoręcznym podpisem na rzecz podpisania wyłącznie przez reprezentanta podmiotu wnoszącego petycję. Postępowanie w sprawie petycji, aczkolwiek odformalizowane, musi się wiązać z pewnym rygoryzmem proceduralnym. Bezspornie niezbędnym elementem każdego pisma jest podpis składającego, jego przedstawiciela ustawowego lub pełnomocnika. Własnoręczny podpis powszechnie uznawany jest za najlepszy gwarant prawdziwości oświadczenia skierowanego do innego podmiotu. Rezygnacja z wymogu złożenia osobistego podpisu pod poparciem udzielonym dla petycji może prowadzić do licznych nadużyć (np. wpisanie osób zmarłych) oraz sytuacji uznania poparcia dla inicjatywy przez osoby, które w rzeczywistości nic o petycji nie wiedza. Regulacja w tym zakresie powinna być jednoznaczna i wyraźna: brak podpisu obok wskazanych danych oznacza, że poparcie nie zostało udzielone. Oba elementy, a więc własnoręczny podpis i oznaczenie wnoszącego (imię i nazwisko oraz adres miejsca zamieszkania) wzajemnie się uzupełniają i dopiero łącznie identyfikują osobę, która wyraziła poparcie dla żądania przedstawionego w petycji. W przypadku petycji zbiorowych wnoszonych przez osoby fizyczne podpis samego reprezentanta nie jest wystarczający i nie powinien przesądzać o rzeczywistej woli wnoszaccych. Nie jest on bowiem pełnomocnikiem podmiotu wnoszącego petycję. Wydaje się, że w założeniu ustawodawcy jego rola miała sprowadzać się do pośredniczenia między organem a grupa podmiotów, aczkolwiek analiza przepisów ustawy nie pozwala na jasne określenie jego pozycji w tym postępowaniu. Osoba reprezentanta została wprowadzona w art. 4, jednak w dalszych przepisach ustawodawca konsekwentnie posługuje się pojęciem „podmiotu wnoszącego petycję" (np. w art. 6, 7, 13). Można jedynie przyjąć, że w sytuacji np. pozostawienia bez rozpoznania petycji wniesionej przez grupę

${ }^{36}$ Zauważyć należy, iż na podstawie $§ 5$ rozporządzenia Rady Ministrów z 8 stycznia 2002 r. w sprawie organizacji przyjmowania i rozpatrywania skarg i wniosków (Dz. U. Nr 5, poz. 46) skargi i wnioski mogą być wnoszone pisemnie, telegraficznie lub za pomoca dalekopisu, telefaksu, poczty elektronicznej, a także ustnie do protokołu. 
osób fizycznych, założeniem ustawodawcy było, aby informacja o tym została doręczona jedynie reprezentantowi, a nie każdemu z tych podmiotów.

Wątpliwości co do swej celowości i racjonalności wywołuje regulacja dotyczacca składania petycji w formie elektronicznej. Stosownie do art. 4 ust. 5 w sytuacji, gdy petycja składana jest za pomocą środków komunikacji elektronicznej, może być opatrzona kwalifikowanym podpisem elektronicznym oraz powinna zawierać także adres poczty elektronicznej podmiotu wnoszącego petycję. Sformułowanie „może być opatrzona kwalifikowanym podpisem elektronicznym" interpretować można co najmniej na dwa sposoby. Pierwsze znaczenie tego zwrotu znaczy tyle, że składanie petycji bez kwalifikowanego podpisu nie jest zakazane. Druga interpretacja skłania do wniosku, iż ustawodawca stworzył podmiotowi upoważnienie do złożenia petycji opatrzonej kwalifikowanym podpisem elektronicznym, z którego nie musi wszakże skorzystać. Redakcja tego przepisu wywołuje lekką konsternację. Skoro bowiem jednostka jest uprawniona do złożenia petycji za pomocą środków komunikacji elektronicznej bez użycia kwalifikowanego podpisu, to oczywistym jest, że tym bardziej jest uprawniona do składania petycji opatrzonej tym podpisem. Normując kwestię składania petycji za pomocą środków komunikacji elektronicznej, ustawodawca powinien jednoznacznie wskazać bądź na obowiązek posługiwania się „kwalifikowanym podpisem elektronicznym”, bądź też na jego brak. Zauważyć należy, że w k.p.a. skuteczne wniesienie skargi lub wniosku w formie elektronicznej nie jest uwarunkowane opatrzeniem kwalifikowanym podpisem. Zamiarem ustawodawcy nie było bowiem ograniczenie możliwości korzystania z tej drogi do wąskiej grupy podmiotów. Uznać zatem należy, że również składanie petycji w formie elektronicznej jest dozwolone, bez konieczności uwierzytelnienia. Petycja nie jest podaniem, które wszczyna jurysdykcyjne postępowanie administracyjne, stąd też wymagania w zakresie opatrzenia „kwalifikowanym podpisem elektronicznym” uznać należałoby za naruszające podstawowe cechy prawa petycji, jakimi są ogólna dostępność i małe sformalizowanie ${ }^{37}$.

Zastrzeżenia wywołuje długość terminów określonych w ustawie. Na wezwanie wnoszacego petycję do uzupełnienia braków formalnych lub wyjaśnienia treści petycji organ ma aż 30 dni. W razie powstania watpliwości co do istnienia lub zakresu zgody podmiotu trzeciego na wniesienie w jego imieniu petycji, adresat petycji również w terminie 30 dni od dnia złożenia petycji może zwrócić się do podmiotu, w interesie którego petycja jest składana, o potwierdzenie zgody (art. 5). Wydaje się, iż 30-dniowe terminy na dokonanie nieskomplikowanych czynności, jakimi są wezwanie do uzupełnienia braków formalnych lub wyjaśnienia przedmiotu petycji bądź do potwierdzenia zgody, sa zdecydowanie zbyt długie i nie wpływają w sposób dynamizujący na przebieg postępowania. Brak również racjonalnych argumentów przemawiających za 30-dniowym terminem na przekazanie petycji organowi właściwemu, zwłaszcza że w dziale VIII k.p.a., który również wykonuje art. 63 Konstytucji, termin przekazania skargi lub wniosku organowi właściwemu następuje nie później niż w ciagu 7 dni (por. art. 231 i 243 k.p.a.). Zbyt długie są również terminy

\footnotetext{
37 E. Wójcicka, Prawo petycji w Rzeczypospolitej Polskiej, Warszawa 2015, s. 306-307.
} 
skierowane do podmiotu wnoszącego petycję, jak chociażby 14-dniowy termin na uzupełnienie braków formalnych. Taki sam termin przewidziano dla podmiotu trzeciego na potwierdzenie zgody. Można się również zastanawiać, czy maksymalny 3-miesięczny termin na rozpatrzenie petycji (w sytuacji wystąpienia okoliczności niezależnych od podmiotu rozpatrującego petycję, uniemożliwiających jej rozpatrzenie, termin ten wyniesie aż 6 miesięcy od dnia jej złożenia) jest terminem rozsądnym.

Należy zwrócić uwagę na brak uregulowania kwestii cofnięcia petycji indywidualnej, wycofania poparcia w przypadku petycji zbiorowej oraz odwołania zgody podmiotu trzeciego, w interesie którego petycja jest składana. Ustawodawca nie określił formy i sposobu złożenia oświadczenia ani skutków procesowych takiej czynności. Początkowo art. 4 ust. 4 projektu ustawy o petycjach przewidywał, iż osoba podpisująca petycję mogła w każdej chwili wycofać swoje poparcie dla petycji. Gdyby swoje poparcie dla petycji wycofały wszystkie osoby, które ją podpisały, wówczas organ pozostawiałby petycję bez rozpatrzenia. Na etapie prac legislacyjnych przepis ten został skreślony. Ustawodawca nie zdecydował się jednak na rozwiązanie znane chociażby z ustawy z 15 września 2000 r. o referendum lokalnym (por. art. 14 ust. 2) ani nie zastrzegł, iż udzielonego poparcia nie można wycofać. Mając jednak na względzie zasadę dyspozycyjności, uznać należy, że cofnięcie petycji indywidualnej jest dopuszczalne. Postępowanie w sprawie petycji wszczynane jest wyłącznie na wniosek, a zatem to jednostka, podejmując decyzję o wszczęciu postępowania, staje się jego dysponentem. To od wnoszacego zależy, czy będzie zmierzał do rozpatrzenia petycji przez organ. W sytuacji gdy jednostka posiada wyłączne uprawnienie do zainicjowania uproszczonego postępowania administracyjnego, tym bardziej służy jej uprawnienie do rezygnacji z jego dalszego prowadzenia. Za dopuszczalne należy również uznać wycofanie poparcia w przypadku petycji zbiorowej ${ }^{38}$. Możliwość wycofania zarówno petycji indywidualnej, jak i poparcia wynika z wolnościowego charakteru prawa petycji, który implikuje treść zachowań podejmowanych przez uprawnione podmioty. Pozytywny aspekt wolności wiąże się z pozostawieniem decyzji o wykonywaniu prawa petycji wyłącznemu uznaniu jednostki, co oznacza, że może ona dowolnie swoje uprawnienie urzeczywistniać albo nie urzeczywistniać.

Powyższe wywody można również odnieść do możliwości odwołania zgody osoby trzeciej na złożenie petycji w jej interesie. Argumentem przemawiającym na korzyść tak postawionej tezy jest przede wszystkim fakultatywność zgody. Uprawnienie do dokonania konkretnej czynności implikuje również uprawnienie do jej odwołania ${ }^{39}$. Do odwołania zgody przez osobę trzecią nie jest wymagane przyzwolenie ani osoby występującej z petycja, ani organu

\footnotetext{
${ }^{38}$ Zwrócić należy uwagę na możliwość cofnięcia petycji składanych do Parlamentu Europejskiego. W myśl art. 215 ust. 4 Regulaminu: Każda osoba składająca petycję może w każdej chwili wycofać poparcie dla petycji. Po wycofaniu poparcia przez wszystkich składających petycję staje się ona bezprzedmiotowa.

39 Szerzej: J. Mokry, Odwołalność czynności procesowych w sqdowym postępowaniu cywilnym, Warszawa 1973, s. 112.
} 
właściwego do rozpatrzenia petycji. Uznać należy, iż cofnięcie zgody możliwe będzie dopóty, dopóki organ nie uzewnętrzni zawiadomienia o sposobie załatwienia petycji.

Odwołanie zgody, wycofanie petycji indywidualnej lub wycofanie poparcia przez wszystkich składających petycję powoduje przerwanie ciągu czynności procesowych organu. Zarówno ustawa o petycjach, jak i k.p.a., który należy stosować odpowiednio, nie regulują konsekwencji takiej czynności dla dalszego bytu postępowania. Z uwagi na niedopuszczalność wydania decyzji o umorzeniu postępowania (nie jest to bowiem postępowanie jurysdykcyjne), za prawidłowe można uznać pozostawienie petycji bez rozpoznania i zawiadomienie o tym wnoszącego.

\section{USTAWA O PETYCJACH A ZASADY POPRAWNEJ LEGISLACJI}

Niezależnie od wskazanych wątpliwości analizowana ustawa wywołuje zastrzeżenia z punktu widzenia zasad techniki prawodawczej. Ustawa o petycjach nie jest obszernym aktem normatywnym ani nie reguluje wszystkich kwestii proceduralnych związanych z jej przedmiotem w sposób kompleksowy. W zakresie nieuregulowanym odsyła do przepisów ustawy z 14 czerwca $1960 \mathrm{r}$. - Kodeks postępowania administracyjnego. Takie ujęcie skłania do poczynienia kilku krytycznych uwag.

Zasadą jest, że odesłań nie można stosować w sposób dowolny. Zgodnie z 156 rozporządzenia Prezesa Rady Ministrów z 20 czerwca 2002 r. w sprawie „Zasad techniki prawodawczej” ${ }^{40} \mathrm{w}$ akcie normatywnym można posłużyć się odesłaniami, jeżeli zachodzi potrzeba osiagnięcia skrótowości tekstu lub zapewnienia spójności regulowanych instytucji prawnych. Ustawa o petycjach liczy jedynie 17 artykułów, w tym trzy ostatnie to przepis odsyłający, zmieniający ustawę k.p.a. i przepis o wejściu ustawy w życie. Wydaje się, że kompleksowe uregulowanie postępowania z petycjami $\mathrm{w}$ jednym akcie normatywnym, bez konieczności odsyłania do innych ustaw, byłoby bardziej pożądane i czytelne. Trudno również przyjąć, że odesłanie do k.p.a. zapewniło spójność regulowanej instytucji prawnej, szczególnie że ustawodawca wyszedł z założenia, iż petycja jest instytucją autonomiczną. Projektodawcy uznali, że „pomimo wspólnej regulacji prawnej w art. 63 prawo petycji jest odrębnym prawem, różnym od skarg i wniosków. Wynika to z określenia tego prawa podmiotowego inną, własną nazwa, wysunięcia petycji w porządku przepisu Konstytucji RP na plan pierwszy, a także historycznych związków z takim prawem w Konstytucji Marcowej z 1921 r." ${ }^{41}$

Ustawodawca, normując tryb rozpatrywania petycji, powinien zdecydować się na jedno z dwóch alternatywnych rozwiązań: albo kompleksowo uregulować instytucję petycji w odrębnej ustawie, albo uregulować całościowo petycje,

${ }^{40}$ Dz. U. 2016, poz. 283.

${ }^{41}$ Uzasadnienie projektu..., s. 8. 
skargi i wnioski w dziale VIII k.p.a. ${ }^{42}$ Legislator wybrał natomiast rozwiązanie trzecie, najmniej czytelne: częściowo uregulował tryb rozpatrywania petycji w odrębnej ustawie - która zresztą powtarza przepisy dotyczące skarg i wniosków - a w zakresie nieuregulowanym odesłał do odpowiedniego stosowania przepisów Kodeksu postępowania administracyjnego. Rozwiązanie to świadczy nie tylko o braku spójnej koncepcji prawa petycji, ale również jest przejawem niekonsekwencji prawodawcy.

Zastosowana technika legislacyjna wywołuje zastrzeżenia, gdyż odesłanie jest zbyt ogólne i pozostawia zbyt daleko idącą swobodę organowi prowadzącemu postępowanie. W praktyce odpowiednie stosowanie k.p.a. będzie wiązało się z poważnymi wątpliwościami co do tego, który przepis Kodeksu będzie stosowany wprost, który w postaci zmodyfikowanej, a który w ogóle nie znajdzie zastosowania do rozpatrywania petycji. Decydując się na odesłanie do k.p.a., ustawodawca winien jednoznacznie wskazać przepisy prawne, do których odsyła. Im dokładniej jest określony zakres „odpowiedniego stosowania”, tym mniejsze prawdopodobieństwo wystapienia problemów interpretacyjnych, czy dany przepis ma w konkretnym przypadku zastosowanie. Mniejsze jest również zagrożenie, że organ rozpatrujący petycję nada temu postępowaniu w sposób nieuprawniony cechy postępowania jurysdykcyjnego.

Niezbędne jest jeszcze przedstawienie jednego zastrzeżenia wobec sposobu sformułowania przepisów ustawy o petycjach. Znaleźć można postanowienia, które wymagają korekty, chociażby ze względu na konieczność zachowania zasad poprawnej legislacji w aspekcie precyzji językowej, spójności, komunikatywności i przejrzystości. Wyraźnie zauważalny jest brak konsekwencji terminologicznej. Na oznaczenie organu właściwego do rozpatrzenia petycji ustawodawca posługuje się następującymi pojęciami:,,adresat petycji” (art. 5), „podmiot rozpatrujący petycję" (art. 10, art. 13, art. 11 ust. 4), „właściwy podmiot” (art. 6) i wreszcie „podmiot właściwy do rozpatrzenia petycji” (art. 11 ust. 3, art. 12, art. 14). Ustawodawca niekonsekwentnie posługuje się również wyrażeniem „adresat petycji”, nadając mu dwa znaczenia. Raz przez pojęcie to rozumie zarówno organ właściwy, jak i niewłaściwy (art. 4 ust. 2 pkt 3). Innym razem zaś używa sformułowania „adresat petycji” jedynie w znaczeniu organu właściwego do rozpatrzenia petycji. W tym drugim znaczeniu posługuje się pojęciem „adresat petycji” w art. 5, normującym sposób postępowania organu w przypadku powstania wątpliwości co do istnienia lub zakresu zgody podmiotu trzeciego. Należy bowiem przyjąć, że wyłącznie organ właściwy będzie wzywał podmiot trzeci do potwierdzenia zgody na złożenie petycji w jego interesie. Ponadto niektóre z przepisów ustawy nie zostały zredagowane w sposób komunikatywny. Można zaryzykować tezę, że skreślenie zbędnych powtórzeń, np. w art. 11 i art. 12 ust. 1 („podmiot właściwy do rozpatrzenia petycji”) nie pozbawiłoby tych przepisów ani funkcjonalności, ani czytelności.

42 Warto przypomnieć, iż zasadność uregulowania petycji w odrębnej ustawie była podawana w wątpliwość na etapie prac legislacyjnych. Zob. A. Jaroszyński, Opinia w sprawie, s. 3. C. Martysz, Opinia w sprawie projektu ustawy o petycjach (druk nr 1036), w: Opinie, s. 6. 


\section{PODSUMOWANIE}

Analiza normatywna ustawy o petycjach prowadzi do wniosku, że przyjęte rozwiązania nie są wystarczająco jasne i precyzyjne. Wydaje się, że zasadniczą przyczyną mankamentów ustawy był brak pomysłu na regulację petycji. Widoczny był on przy każdej próbie ustawowego uregulowania trybu rozpatrywania petycji, począwszy od rządowego projektu zmiany k.p.a. w 1999 r., a na senackim projekcie z 2013 r. skończywszy. Zauważalny był również podczas prac nad ustawą z 7 lipca 2005 r. o działalności lobbingowej w procesie stanowienia prawa, zwłaszcza zaś przy nieudanych próbach wyraźnego odróżnienia tych dwóch instytucji i wytyczenia granic między wykonywaniem prawa petycji a prowadzeniem działalności lobbingowej. Zresztą również ustawa o petycjach nie podejmuje kwestii wzajemnej relacji między prawem petycji a lobbingiem.

Choć to Konstytucja RP wyznacza ramy prawa petycji, to ustawa zwykła pełni ważna rolę - reguluje zasady i tryb rozpatrywania petycji, dzięki czemu prawo to może się urzeczywistnić. Aby ustawa stanowiła skuteczną gwarancję realizacji prawa petycji, jej przepisy muszą być dokładne i zrozumiałe dla adresatów, sama zaś ustawa powinna być regulacją samodzielną i wyczerpująca. Do pewnych założeń i rozwiązań ustawy o petycjach, takich jak odformalizowana procedura czy szeroki zakres podmiotowy, należy się odnieść z aprobata. Niemniej jednak ustawa nie jest wolna od wad utrudniajacych stosowanie jej w praktyce, a tylko niektóre z nich mogą zostać skorygowane odpowiednimi metodami wykładni prawa. Główny mankament związany jest z tym, że ustawa nie odróżnia petycji od skarg i wniosków, a tym samym nie usuwa wątpliwości co do wzajemnych zależności między tymi instrumentami. Twórcy ustawy z 11 lipca 2014 r. o petycjach, zamiast wykorzystać doświadczenia i wnioski płynące z poprzednich prac legislacyjnych, powrócili do rozwiązań, które spotkały się z miażdżąca krytyką i były przyczyną wycofania projektów ustaw z sejmu (kazus „życia zbiorowego”). W świetle poczynionych uwag można dostrzec potrzebę nowelizacji przepisów, tak aby ustawa w pełni służyła realizacji normatywnego celu określonego w art. 63 Konstytucji, czyli zagwarantowaniu każdemu możliwości realnego udziału w kierowaniu sprawami publicznymi.

dr Ewa Wójcicka

Akademia im. Jana Dtugosza w Częstochowie

e.wojcicka@ajd.czest.pl

ACT OF 11 JULY 2014 ON PETITIONS - SOME CRITICAL REMARKS

Sum mary

Petitioning is one of the basic rights. Pursuant to Article 63 of the Constitution of the Republic of Poland everyone has the right to submit petitions, proposals and complaints in the public interest, in one's own interest or in the interests of another person - with this person's consent - to organs of public authority, as well as to organisations and social institutions regarding matters 
connected with the performance of their prescribed duties within the field of public administration. The procedure for considering petitions is specified in the Act of 11 July 2014 on petitions (Dziennik Ustaw 2014, item 1195). This act came into force on 6 September 2015. The purpose of this article is to show the origins of the Polish petitioning legislation and, particularly, to provide a critical analysis of the act on petitions. The results of the analysis allow to draw up a conclusion that the solutions currently adopted lack clarity and precision. The main critical argument is that the act does not define the term of petition in an explicit and unambiguous way. Ipso facto it also fails to eliminate doubts related to the relationships between petitions and complaints or proposals. 